\title{
Systematic review of the factors affecting cat and dog owner compliance with pharmaceutical treatment recommendations
}

Dr Kathryn Jennifer Wareham PhD BVetMed(Hons) MRCVS Centre for Evidence-based Veterinary Medicine, School of Veterinary Medicine and Science, The University of Nottingham, Sutton Bonington campus, Loughborough, LE12 5RD, UK

Dr Marnie Brennan Centre for Evidence-based Veterinary Medicine, School of Veterinary Medicine and Science, The University of Nottingham, Sutton Bonington campus, Loughborough, LE12 5RD, UK Dr Rachel Dean BVMS PhD MSc(EBHC) DSAM(fel) SFHEA MRCVS. Director of Clinical Research and Excellence in Practice. VetPartners Ltd, Leeman House, Station business park, Holgate Park Drive, York YO26 4GB.

Corresponding author: Dr Rachel Dean; rachel.dean@nottingham.ac.uk

\begin{abstract}
The aim of this systematic review is to describe and assess the quality of the existing evidence base concerning factors that influence the compliance of cat and dog owners to pharmaceutical and specifically polypharmacy treatment recommendations.

PubMed, CAB Abstracts and Google, were searched to identify relevant literature and search results were filtered according to pre-determined inclusion and exclusion criteria. Standardised data extraction and critical appraisal was carried out on each included study and a Centre for EvidenceBased Medicine (CEBM) level of evidence grading applied.

Of the 8589 studies, 8 studies were included in the review. The majority (5/8) of the included studies were examining compliance with short term antimicrobial therapies and none examined polypharmacy. Multiple definitions of compliance, methods of measurement, and different factors potentially affecting compliance, were used. Factors reported to have affected compliance in at least one study were; the dosing regime, discussion of the dosing regime in light of the owners circumstances, consultation time, the disease, the month of the consultation/treatment, physical risk, social risk, and method of administration.

The evidence available regarding factors affecting client compliance with pharmaceutical treatment recommendations in cats and dogs is scarce and of poor quality.
\end{abstract}

\section{Introduction}

Numerous medications are widely available to small animal practitioners and their clients, with many conditions now having multiple licensed and unlicensed therapies that can alleviate signs of disease. How well owners comply with, or adhere to, treatment recommendations made by veterinary surgeons can significantly affect the success of using these medications and the subsequent health outcomes for the patients. Compliance can be described as: 
'the consistency and accuracy with which a patient follows the regimen prescribed by a physician or other health care professionals' [Stedman's online medical dictionary; www.stedmans.com]

Compliance (and adherence) includes not only whether the medication is administered, but also the accuracy of the dose that is administered and whether the patients receive it 'on time'. In order to maximise compliance, it is important to understand the factors affecting whether a client will comply with the recommendations made by the veterinarian. The factors affecting compliance may also vary depending on the specific condition being treated, the duration of treatment required and whether multiple medications are prescribed, amongst other things. Understanding this complex phenomenon could provide opportunity to alter behaviours of both the prescriber and the client, improve compliance and ultimately improve the health of the patients.

Many systematic reviews have been undertaken in human medicine attempting to assess what factors affect compliance, with a view to implementing effective intervention strategies to improve it. Compliance research in the medical field has been carried out across various conditions, including those that require polypharmacy, and many different types of interventions have been tested including simplified dosing regimens, patient education and support, medication reminders, limiting economic impacts on the patient and drug formulation ${ }^{1-4}$. Overall, there have been very few proposed successful interventions for improving compliance amongst medical patients ${ }^{2}$, with simplified dosing regimens, coverage of prescription costs and educational interventions having shown some positive effects on compliance ${ }^{3,5} 4$ across different disciplines. It is unclear if the factors affecting compliance in medical patients translate to the compliance behaviour of veterinary clients and their pets.

A systematic review of this topic is the first of its kind in veterinary medicine and will provide a good understanding of the evidence base regarding factors affecting client compliance with pharmaceutical treatment recommendations in small animal practice; it is a crucial first step in being able to improve compliance.

Aims

To describe and assess the quality of the existing published evidence base concerning factors that influence the compliance of cat and dog owners to pharmaceutical treatment recommendations by veterinary prescribers.

A secondary aim is to describe and assess the quality of the existing published evidence base concerning factors that influence the compliance of cat and dog owners to polypharmacy pharmaceutical treatment recommendations by veterinary prescribers.

\section{Materials and methods}


Search strategy

To identify relevant literature, strategic searches using keywords and subject headings were performed in Medline and CAB Abstracts literature databases (February 2016) using OVID and in Google (April 2016); search terms used can be found in Table 1.

Table 1: Search terms used to search MEDLINE and CAB Abstracts (OVID) literature databases and Google

\begin{tabular}{|c|c|}
\hline Search location & Search terms \\
\hline $\begin{array}{l}\text { Ovid MEDLINE® In-Process \& Other } \\
\text { Non-Indexed Citations and Ovid } \\
\text { MEDLINE } ₫ 1946 \text { to present }\end{array}$ & $\begin{array}{c}\text { (cat.mp. OR cats.mp. OR feline.mp. OR felines.mp. } \\
\text { OR felis.mp. OR exp cats/ OR dog.mp. OR } \\
\text { dogs.mp. OR canine.mp. OR canines.mp. OR } \\
\text { canis.mp. OR exp dogs/ OR veterinary.mp. OR exp } \\
\text { veterinary medicine/) } \\
\text { AND } \\
\text { (Complian*.mp. OR adher*.mp. OR } \\
\text { concordan*.mp. OR exp patient compliance/ OR } \\
\text { exp medication adherence/) }\end{array}$ \\
\hline CAB Abstracts 1910-2016 & $\begin{array}{c}\text { (cat.mp. OR cats.mp. OR feline.mp. OR felines.mp. } \\
\text { OR felis.mp. OR exp cats/ OR dog.mp. OR } \\
\text { dogs.mp. OR canine.mp. OR canines.mp. OR } \\
\text { canis.mp. OR exp dogs/ OR veterinary.mp. OR exp } \\
\text { veterinary medicine/) } \\
\text { AND } \\
\text { (Complian*.mp. OR adher.mp. OR } \\
\text { concordan*.mp. OR exp patient compliance/) }\end{array}$ \\
\hline Google (www.google.co.uk) & $\begin{array}{c}\text { (cat OR cats OR feline OR felines OR felis OR dog OR } \\
\text { dogs OR canine OR canines OR canis OR veterinary) } \\
\text { AND } \\
\text { (compliance OR compliant OR adherence OR } \\
\text { adhere OR adhering OR adherent OR } \\
\text { concordance OR concordant) }\end{array}$ \\
\hline
\end{tabular}

\section{Filtering of search results}

Search results from CAB Abstracts and MEDLINE literature databases were imported into Endnote for sorting. Duplicates were removed and results filtered by title and abstract screening, followed by full text screening when required, according to the inclusion and exclusion criteria in Table 2. Two authors (KW and RD) filtered all the results from these searches independently. The first 800 hits in the Google search were filtered 'live' in Google by two authors (KW/RD) together, according to the same inclusion and exclusion criteria. For all sorting, a third author (MB) resolved any disagreements. Foreign language papers that were not excluded by title/abstract screening were read by a translator to check for relevant content. Full text translation was performed if necessary to determine whether the article fulfilled the inclusion criteria.

Data extraction from included studies 
Data extraction on the included studies was performed using a standardised Excel form by one author $(\mathrm{KW})$ and verified by a second author (RD/MB), disagreements were resolved by discussion.

Information extracted included; study design, study setting, sample size, sample description, whether polypharmacy was used, the main findings of the study, factors affecting compliance proposed from the study, factors affecting compliance tested in the study and their effect on compliance.

\section{Quality assessment of included studies}

Critical appraisal of the included studies was performed using standardised critical appraisal checklists in use at the Centre for Evidence-based Veterinary Medicine (CEVM; www.nottingham.ac.uk/cevm). The corresponding checklist was used for each study type as appropriate; the critical appraisal checklist most appropriate to the compliance aspect of the study was used, regardless of the main aim of the study (e.g. if the main study was a randomised controlled trial (RCT) examining efficacy, but the compliance aspect of the report was a descriptive study, the standard critical appraisal checklist was used instead of the RCT checklist). The completed critical appraisals were used to identify any study weaknesses. Critical appraisal was performed by one author $(\mathrm{KW})$ and verified by a second author $(\mathrm{RD} / \mathrm{MB})$ with disagreements resolved by discussion.

\section{Grading of the included evidence}

The level of evidence provided by included studies where factors potentially affecting compliance were tested was determined using The 2011 Centre for Evidence-Based Medicine (CEBM) grading system $^{6-8}$. Included studies where factors potentially affecting compliance were described or proposed from the data, as opposed to tested, were not graded.

Table 2: Inclusion and exclusion criteria for filtering search outputs

\begin{tabular}{|l|l|l|}
\hline $\begin{array}{l}\text { Criteria } \\
\text { interest }\end{array}$ & $\begin{array}{l}\text { Onclusion } \\
\text { pharmaceutical agent is being a } \\
\text { recommended for therapeutic effect by } \\
\text { a veterinary prescriber and is to be } \\
\text { administered at home }\end{array}$ & $\begin{array}{l}\text { Large animal and equine clients, small } \\
\text { animal clients not relating to cats and } \\
\text { dogs } \\
\text { Medical practice } \\
\text { Therapeutic agents being used } \\
\text { prophylactically i.e. preventive medicine } \\
\text { Prescription diets } \\
\text { Therapeutic agents to be administered } \\
\text { in clinics or by veterinary staff }\end{array}$ \\
\hline Outcome & $\begin{array}{l}\text { Contain an assessment, or description, } \\
\text { of factors affecting } \\
\text { compliance/concordance/adherence to } \\
\text { veterinary therapeutic treatment } \\
\text { recommendations relating to dogs and } \\
\text { cats }\end{array}$ & $\begin{array}{l}\text { Do not contain an assessment or } \\
\text { description of factors affecting } \\
\text { compliance/concordance/adherence to } \\
\text { veterinary therapeutic treatment } \\
\text { recommendations relating to dogs and } \\
\text { cats }\end{array}$ \\
\hline
\end{tabular}




\begin{tabular}{|l|l|l|}
\hline $\begin{array}{l}\text { Publication } \\
\text { type }\end{array}$ & $\begin{array}{l}\text { Full study reported } \\
\text { Peer-reviewed published literature }\end{array}$ & $\begin{array}{l}\text { Abstracts only } \\
\text { Non peer-reviewed published literature } \\
\text { Grey literature } \\
\text { Conference proceedings } \\
\text { Book chapters } \\
\text { Theses }\end{array}$ \\
\hline Study type * & $\begin{array}{l}\text { Randomised controlled trials } \\
\text { Cohort studies } \\
\text { Cross-sectional studies } \\
\text { Case reports/series } \\
\text { Qualitative studies }\end{array}$ & Narrative reviews \\
\hline Availability & $\begin{array}{l}\text { Able to obtain through University Of } \\
\text { Nottingham library or inter-library loan, } \\
\text { or by direct request to authors }\end{array}$ & Unable to obtain full manuscript \\
\hline Language & All languages & \\
\hline
\end{tabular}

${ }^{*}$ Study type definitions in Supplementary Material 1.

\section{Results}

\section{Literature searches and filtering}

CAB Abstracts and MEDLINE searches returned 2405 and 6184 papers respectively, giving a total of 8589 papers. 1109 duplicates were removed leaving 7480 papers to be filtered by title/abstract/full text screening. 7472 papers were excluded, therefore, eight studies fulfilling the inclusion criteria remained in this review. Of the 800 hits filtered in the Google search, 795 were duplicates or excluded and the five remaining articles were already included from the CAB Abstracts and MEDLINE searches; see Figure 1 for a flow diagram of the search results and filtering process.

\section{Main characteristics of the included studies}

The summary characteristics of all included trials are displayed in Table 3 (Supplementary Material 2). Of the eight included studies, all but one were directly examining owner compliance, and the factors associated with owner compliance, with therapeutic treatment recommendations in cats and dogs in a small animal practice setting. The remaining study was an efficacy study which also reported some indicators of owner compliance. None of the included studies examined polypharmacy or multimodal therapies. Regarding the compliance aspects of the studies, the included studies comprised two RCTs, three cohort studies, one case series and two cross sectional questionnaire studies, with one of the RCTs additionally including a cross sectional questionnaire.

The majority of the studies (5/8) examined compliance with short term administration of anti-microbial medications, one of these being topical administration for otitis externa ${ }^{9}$, the remainder being oral antibiotics for acute bacterial infections ${ }^{10-13}$. One study examined compliance with treatment for atopy (hypo sensitisation by allergen injection) ${ }^{14}$, one for mammary neoplasia ${ }^{15}$, and the therapeutic area of the remaining study was not identified ${ }^{16}$. The longest treatment periods and follow up of compliance were in the atopy study where compliance was examined from commencement of treatment to a 
maximum of seven years. Only one study included cats and their owners ${ }^{16}$, the rest exclusively related to dogs. Compliance levels were measured using a range of different methods across the eight studies including owner self-reporting of missed doses, pill counting, electronic medication monitoring, and reviewing repeat medication orders.

\section{Main findings of the included studies}

The main findings of each included study, including the level of client compliance observed, can be found in Table 3. Levels of compliance were very dependent on the measurement methods employed, and the definition of compliance used in the study.

Six of the studies $9,11,13,14,16,17$ tested factors potentially affecting compliance in our target population; within these a large number of different factors were tested. The tested factors, along with whether they influenced compliance or not, can be found in Table 4. Of the factors tested, the following were reported to have affected compliance in at least one of the included studies; once versus three times daily dosing, twice versus three times daily dosing, discussion of the dosing regime in light of the owners circumstances, consultation time spent with the vet, the disease condition being treated, the month of the consultation/treatment, physical risk, social risk, and product pump administration once daily for 5 days compared to standard drops twice daily for seven days for topical treatment of otitis externa in dogs.

There were very few identical factors tested across more than one study. Twice versus three times daily dosing was tested as a factor in three of the studies with conflicting results. One cohort study reported that three times daily dosing compared to twice reduced compliance ${ }^{17}$, compared to one small RCT and one cohort study reporting there was no difference in compliance ${ }^{11,13}$. The specific disease condition being treated also produced conflicting results; with an influence on compliance in one cohort study (treatment of gastrointestinal infections was associated with higher compliance levels than wound infections ${ }^{13}$ ) but no effect in another ${ }^{17}$. Similar factors tested in more than one study but which unanimously had no effect on compliance were: route of administration of medication, treatment outcome/effect of treatment, owners employment in relation to the dosing regime and whether the owner knew what disease was being treated.

The remaining two studies ${ }^{12,15}$ only proposed factors arising from the data that could influence client compliance as opposed to testing them. Two of the six studies ${ }^{9,14}$ described above, also proposed factors affecting client compliance in addition to the factors that were tested. These proposed factors can be found in Table 5. 
Table 4: Summary of results, study weaknesses and evidence level grading of included studies where potential factors affecting compliance were tested, $N=6$.

\begin{tabular}{|c|c|c|c|c|}
\hline Study reference & Factors affecting compliance tested in the study & $\begin{array}{l}\text { Affected } \\
\text { compliance } \\
\text { (Yes/No/Described } \\
\text { only/No results } \\
\text { reported) }\end{array}$ & Study weaknesses & $\begin{array}{l}\text { Evidence level } \\
\text { grading }\end{array}$ \\
\hline Adams et al, $2005^{17}$. & $\begin{array}{l}\text { Number of daily doses } 1 \text { vs } 2 \\
\text { Number of daily doses } 1 \text { vs } 3 \\
\text { Number of daily doses } 2 \text { vs } 3 \\
\text { Discussion of dosing regime in light of client } \\
\text { circumstances } \\
\text { Severity of disease - according to vet } \\
\text { Treatment outcome } \\
\text { Specific drug prescribed } \\
\text { Length of treatment } \\
\text { Specific disease condition - according to vet } \\
\text { Pet very important to client } \\
\text { Client and pet close relationship } \\
\text { Veterinarian prediction of compliance } \\
\text { Specific disease condition - according to client (whether } \\
\text { they could name it } \\
\text { Member of family closest to pet } \\
\text { Member of family giving most medication } \\
\text { Trouble giving medication to pet - client reported } \\
\text { How did you give medication - e.g. mouth/food } \\
\text { Missing a dose due to work a problem for you } \\
\text { Strength of vet-client-patient relationship } \\
\text { Human animal bond } \\
\text { Number of doses reported missed by owner }\end{array}$ & $\begin{array}{l}\text { No } \\
\text { Yes } \\
\text { Yes } \\
\text { Yes } \\
\text { No } \\
\text { No } \\
\text { No } \\
\text { No } \\
\text { No } \\
\text { No } \\
\text { No } \\
\text { No } \\
\text { No } \\
\text { No } \\
\text { No } \\
\text { No } \\
\text { No } \\
\text { No } \\
\text { No } \\
\text { No } \\
\text { No }\end{array}$ & $\begin{array}{l}\text { - } \quad \text { Lack of details given on how } \\
\text { some of the exposures data } \\
\text { were obtained } \\
\text { - } \quad \text { No justification of the sample } \\
\text { size used } \\
\text { - } \quad \text { Some subjective outcome } \\
\text { measures and reliance on } \\
\text { self-reporting of clients for } \\
\text { some measures } \\
\text { - Subjective reporting of some } \\
\text { exposures with no validation } \\
\text { provided } \\
\text { Not all variables tested for } \\
\text { effect on compliance fully } \\
\text { discussed } \\
\text { Enrolment was intended to } \\
\text { be consecutive cases but } \\
\text { ended up being a } \\
\text { convenience sample } \\
\text { potentially introducing } \\
\text { selection bias } \\
\text { Pharmaceutical funding }\end{array}$ & CEBM level 3 \\
\hline Barter et al, 1996 ${ }^{11}$. & Twice versus three times daily dosing & No & $\begin{array}{ll}\text { - } & \text { No details given on how } \\
\text { randomisation was } \\
\text { performed } \\
\text { - No information on whether } \\
\text { allocation concealment or } \\
\text { blinding was performed } \\
\text { - No justification of the sample } \\
\text { size and small sample size } \\
\text { used }\end{array}$ & CEBM Level 2 \\
\hline
\end{tabular}




\begin{tabular}{|c|c|c|c|c|}
\hline & & & $\begin{array}{l}\text { - Very brief description of } \\
\text { statistical methods and no } \\
\text { statistical significance level } \\
\text { stated in the methods } \\
\text { - } \quad \text { Pharmaceutical funding }\end{array}$ & \\
\hline Boda et al, $2011^{9}$. & $\begin{array}{l}\text { Product pump administration once daily for } 5 d \text { compared } \\
\text { to standard drops twice daily for } 7 d\end{array}$ & Yes & $\begin{array}{ll}\text { - } & \text { No details given on how } \\
\text { randomisation was } \\
\text { performed } \\
\text { - } \quad \text { No justification of the sample } \\
\text { size used } \\
\text { - } \quad \text { No blinding used } \\
\text { - No statistical significance } \\
\text { level stated in the methods } \\
\text { - } \quad \text { No funding source stated } \\
\text { Pharmaceutical company } \\
\text { involvement (author } \\
\text { employment) }\end{array}$ & CEBM Level 2 \\
\hline Grave et al, $1999^{13}$. & $\begin{array}{l}\text { Consultation (time spent with vet) } \\
\text { Information about use of drug } \\
\text { The disease condition } \\
\text { One tablet twice daily versus one tablet three times daily } \\
\text { (treatment regimen) } \\
\text { Effect of treatment } \\
\text { Administration of tablets (route) } \\
\text { Owner perception of severity of disease } \\
\text { Owners employment (relation to dosing regimen) } \\
\text { Size of dog } \\
\text { Start of treatment (how soon after consultation) } \\
\text { Owners knowing the disease being treated } \\
\text { Consulting/treatment month }\end{array}$ & $\begin{array}{l}\text { Yes } \\
\text { No } \\
\text { Yes } \\
\text { No } \\
\text { No } \\
\text { No } \\
\text { No } \\
\text { No } \\
\text { No } \\
\text { No } \\
\text { No } \\
\text { Yes }\end{array}$ & $\begin{array}{ll}\text { - } & \text { Reliance on self-reporting } \\
\text { from clients for compliance } \\
\text { determination } \\
\text { - } \quad \text { Lack of detailed information } \\
\text { on how the telephone } \\
\text { interviews were conducted } \\
\text { and therefore how exposures } \\
\text { were measured } \\
\text { - No justification of the sample } \\
\text { size used } \\
\text { - Numbers presented in } \\
\text { results don't always add up, } \\
\text { difficult to follow all subjects } \\
\text { through the study } \\
\text { - No funding source stated } \\
\text { - No effect sizes presented } \\
\text { No discussion of potential } \\
\text { confounding factors }\end{array}$ & CEBM Level 3 \\
\hline Maille et al, $2013^{16}$ & $\begin{array}{l}\text { Physical risk } \\
\text { Social risk }\end{array}$ & $\begin{array}{l}\text { Yes } \\
\text { Yes }\end{array}$ & $\begin{array}{l}\text { - Lacking in details on } \\
\text { methods especially } \\
\text { questionnaire content } \\
\text { Lack of detail on the } \\
\text { characteristics of the } \\
\text { participating owners/animals } \\
\text { e.g. what treatment was, }\end{array}$ & Unclear \\
\hline
\end{tabular}




\begin{tabular}{|c|c|c|c|c|}
\hline & & & $\begin{array}{l}\text { duration of treatment etc } \\
\text { making it difficult to be able } \\
\text { to apply the information to a } \\
\text { population } \\
\text { - No justification of the sample } \\
\text { size used } \\
\text { - Statistical significance level } \\
\text { not stated in the methods } \\
\text { Lack of full reporting of basic } \\
\text { data makes it hard to follow } \\
\text { subjects through the study }\end{array}$ & \\
\hline Saevik et al, $2002^{14}$. & $\begin{array}{l}\text { Owners awareness that induction was } 9 \text { months } \\
\text { Owners awareness that treatment would be lifelong }\end{array}$ & $\begin{array}{l}\text { Described only } \\
\text { Described only }\end{array}$ & $\begin{array}{l}\text { - Unclear if all eligible subjects } \\
\text { were included in the study } \\
\text { - Likely to be high chance of } \\
\text { recall bias due to long } \\
\text { durations of treatment } \\
\text { - Lack of detail regarding what } \\
\text { information was collected at } \\
\text { owner interviews } \\
\text { - No statistical analysis of the } \\
\text { data, no estimate of effect } \\
\text { size given } \\
\text { - No justification of the sample } \\
\text { size used }\end{array}$ & CEBM Level 3 \\
\hline
\end{tabular}


Table 5: Summary of results and study weaknesses of included studies where potential factors affecting compliance were described, $N=4$.

\begin{tabular}{|c|c|c|}
\hline Study reference & $\begin{array}{l}\text { Factors potentially affecting compliance identified in the } \\
\text { study }\end{array}$ & Study weaknesses \\
\hline Boda et al, 20119. & $\begin{array}{l}\text { Wrong duration/frequency of treatment applied } \\
\text { Difficulty in applying the right dose } \\
\text { Misunderstanding of the medical condition } \\
\text { Reliability of the owner } \\
\text { Satisfaction with positive features of the product Dissatisfaction with } \\
\text { negative features of the product } \\
\text { Satisfaction with duration of treatment } \\
\text { Satisfaction with frequency of treatment } \\
\text { Global satisfaction with the product } \\
\text { Satisfaction with ease of use of the product (by veterinarians) }\end{array}$ & $\begin{array}{l}\text { - Questionnaire subjective and not validated } \\
\text { - Not enough detail provided about the questionnaire } \\
\text { itself }\end{array}$ \\
\hline Bomzon et al, $1978^{12}$. & Unable to comply with instructions due to being at work during the day & $\begin{array}{l}\text { - Subjective questioning of owners } \\
\text { - Lack of full discussion on possible factors affecting } \\
\text { owners responses to questioning }\end{array}$ \\
\hline Morris et al, $1993^{15}$. & $\begin{array}{l}\text { Owner refusal (after initial consent) } \\
\text { Animal unwell }\end{array}$ & $\begin{array}{l}\text { - Aim of the study not relating to compliance therefore } \\
\text { study not designed to specifically assess compliance } \\
\text { No details on questioning of owners, unclear how data } \\
\text { relating to compliance was obtained }\end{array}$ \\
\hline Saevik et al, $2002^{14}$. & $\begin{array}{l}\text { No noticeable improvement } \\
\text { Good response } \\
\text { Worsening of problem } \\
\text { Allergens too expensive } \\
\text { Unable to give the dog injections } \\
\text { Difficulty in obtaining renewal orders } \\
\text { Unrelated illness/death } \\
\text { Too time consuming } \\
\text { Change of owner }\end{array}$ & $\begin{array}{l}\text { - No details on how owners were questioned to obtain } \\
\text { the information } \\
\text { - Likely risk of recall bias due to long durations of } \\
\text { treatment }\end{array}$ \\
\hline
\end{tabular}




\section{Quality assessment of the included studies}

All eight of the included studies were critically appraised and their study weaknesses can be found in Tables 4 and 5 . The six studies which tested factors potentially affecting client compliance were assigned a CEBM level of evidence grading based on their study design and quality. There were no Level 1 (highest level e.g. systematic reviews) sources of evidence found with our searches. The two RCTs were assigned as evidence grading level 2, the three cohort studies were graded as level 3 evidence, and the cross sectional questionnaire as 'unclear'. In terms of key quality criteria, both $\mathrm{RCTs}^{9,11}$ failed to report how randomisation was performed, whether allocation concealment was ensured and whether blinding was employed. The cohort studies ${ }^{10,18,19}$ all lacked detail in how exposures and outcomes were measured and largely relied on subjective measurements. All the included studies failed to report a sample size calculation, or a justification of the sample size that was used.

\section{Discussion}

This is the first systematic review of the veterinary literature examining cat and dog owner compliance with veterinary therapeutic recommendations. Overall, 8 studies were found that could be included in this review with varying study designs and qualities. The majority of the studies examined short term compliance with antimicrobial therapies with the only chronic treatment examined being hyposensitisation injections for atopy in dogs. Actual levels of client compliance varied depending on how compliance was defined and measured. The included studies were not similar enough in design, or population studied, to be able to produce one overall combined estimate of the level of client compliance observed.

The majority of the factors potentially affecting compliance that have been tested within the studies in this review, have only been tested in one randomised controlled trial or cohort study (Level 2 or 3 evidence), and all have significant methodological weaknesses that could have biased their results. For the two factors that demonstrated an effect on compliance and were tested in more than one study, there were conflicting results and without further evidence it is difficult to assert with any strength any changes that could be implemented to improve client compliance in our target population.

Client compliance with recommended therapies is an important factor in the success of treatments and can heavily influence outcomes in our patients. The varying levels of compliance reported in the studies in this review are also seen in the medical literature where adherence rates average around $50 \%$, but range from $0 \%$ to over $100 \%^{2}$. One of the major problems highlighted by this review in examining compliance is the differing ways in which it is defined and measured. A consensus on a veterinary definition and accepted level of defining 'compliant clients' would be beneficial going forwards in this field of research, for example, the medical literature often defines non-adherence as taking less than $80 \%$ of prescribed doses ${ }^{2}$. Consistency in how compliance is measured, with less 
reliance on subjective measures, would also be beneficial. Studies which assess compliance alongside clinical outcomes are also required to further our knowledge in this field, as it is difficult to truly gauge any positive impact of an intervention strategy on patients without measuring both².

In addition to a lack of consistency in defining compliance, there was a wide range of descriptions of the factors being tested in the included studies making combining and comparing the results to produce meaningful recommendations very difficult. The overall large number of different factors being tested is understandable given the broad nature of the topic and the lack of current knowledge on which factors are potentially important, but unfortunately this means that the evidence base on any one factor is very limited. Also, some of the factors being tested across studies potentially have the same meaning but are described differently and therefore cannot be directly compared. Some of the proposed factors that could potentially affect client compliance have been extrapolated from human literature and then tested in a veterinary setting. It can not be assumed the two settings are the same but in certain circumstances where carers are involved in helping patients take medications (e.g. paediatrics) in human healthcare the issues around compliance may be more similar to veterinary medicine.

Some of the factors being tested in these studies have been tested in human compliance studies, including dosing regimen. In this review, once or twice daily dosing compared to three times daily dosing was found to positively impact on compliance in one of the included studies, but not in two others. Reducing the number of daily doses to improve compliance has also been tested in human compliance studies with positive effect ${ }^{4,5}$. The two cohort studies within this review that tested twice versus three times daily dosing with conflicting results were both reasonably large (90 and 95 participants) and both had some methodological weaknesses; the randomised controlled trial reporting no effect on compliance of this factor was very small (22 participants). One of the cohort studies finding positive impact of once or twice daily dosing compared to three times daily dosing additionally found no positive effect on compliance of reducing twice daily dosing to once daily ${ }^{17}$; this was hypothesised to be due to the small sample size of dogs being prescribed once daily medication. It was additionally proposed by the authors of the study that missing one dose when on a once daily regime could potentially have more negative impact that missing one dose whilst on a twice daily regime ${ }^{17}$, another factor to be considered when examining effects of compliance. A further, larger randomised controlled trial examining the effect of dosing regimen on client compliance would be very beneficial in determining optimum dosing regimens for client compliance.

Many conditions for which we prescribe treatments in veterinary work require more than one therapeutic agent for treatment, especially in chronic disease, or older animals with multiple comorbidities. We found no relevant evidence in our review relating to client compliance with polypharmacy treatment recommendations in dogs and cats. In humans, polypharmacy has been associated with reduced compliance rates in elderly patients ${ }^{20}$, but a recent systematic review highlighted the fact that there was scarce evidence on the topic and no significant benefits of any one 
approach to improving compliance in such a setting was identified ${ }^{21}$. One potentially promising strategy aimed at improving compliance with polypharmacy in human cardiovascular medicine is the 'polypill', or fixed dose combination therapy. This is where multiple cardiovascular therapies have been combined into one single daily pill; this has recently been trialled and so far has been shown to have positive effects on both adherence and some clinical outcomes ${ }^{22}$. More work on this area is required in the human field and is a potential avenue that could be explored in the veterinary field in the future.

In extracting the results from, and assessing the quality of, the studies included in this review, one of the major problems encountered was a lack of sufficient reporting of details concerning how data was collected and analysed, and how results have been described. Reporting deficiencies, such as failing to report how randomisation of participants was performed, are a common problem identified in both medical and veterinary literature and it has been shown many times that such deficiencies can heavily influence the results of a study ${ }^{23-26}$. Through failing to report how randomisation was performed, and whether allocation concealment and blinding were ensured, the RCTs in this study are open to risks of selection bias and performance bias which could have influenced their results. In some cases, studies may actually be methodologically sound, but unless sufficient information is reported it is impossible to assess ${ }^{27,28}$. The use of reporting guidelines when writing up research studies, such as the CONSORT checklist for randomised controlled trials ${ }^{29}$ and the STROBE checklist for observational studies ${ }^{30}$, should help to improve this situation. The endorsement of, and requirement to use, these guidelines by journals could further this potential impact.

\section{Limitations of the study}

CAB Abstracts and MEDLINE literature databases were searched as we know from previous research that these give us good coverage (over $90 \%$ ) of the veterinary literature ${ }^{31}$. An additional Google search helped to ensure that other potential sources of evidence relevant to our objective would be identified but there is always the possibility that relevant literature exists that was not found and therefore included in this review. Time and financial constraints limited searching to major databases and Google and necessitated the exclusion of grey and non peer-reviewed literature from this review which could have an impact on our findings. It is also possible relevant evidence has been missed due to the nature of the information we were looking for in this review; compliance may have been studied but if it was not the main focus of a study it would potentially not be mentioned in the title and abstract of a manuscript. It was not possible to read the full text of all articles found in the searches in order to identify such evidence. We have not looked for the presence of publication bias and assessed any impact this may have had on our review. Time and financial constraints also limited us to one author performing data extraction with a second verifying the findings, rather than two authors independently extracting data. This review has focused on client compliance with the administration of therapeutic pharmaceuticals in dogs and cats, there is however further evidence available concerning compliance in other veterinary fields e.g. preventive medicine, dental treatment, and in other species, which may contain useful information that can be applied across disciplines ${ }^{32-34}$. 


\section{Conclusion}

Overall, there is very limited evidence, in both quantity and quality, concerning the factors affecting client compliance with therapeutic pharmaceutical treatment recommendations in cats and dogs, and no evidence at all was found to address our second aim concerning compliance with polypharmacy. The lack of evidence does not mean there is no possibility of improving compliance and it is important that the knowledge base is improved. Further studies specifically aimed at examining and testing factors affecting compliance in veterinary practice would be extremely beneficial to further our knowledge and understanding of how best to maximise compliance and subsequently improve the health of our patients. In particular, relevant to our second aim, studies are required to examine how compliance is affected when multiple therapies are needed to treat chronic diseases commonly seen in companion animal practice. The further research needed includes both qualitative studies to explore and propose the factors affecting client compliance, along with randomised controlled trials to test factors affecting compliance. Qualitative studies allow us to identify which factors are potentially important to client compliance without making assumptions which could well be incorrect, the proposed factors can then be tested formally in randomised controlled trials. Whilst some factors affecting compliance may be important across all situations, it is possible that situation specific details including the disease condition itself, severity of the disease, type of treatment, and chronicity of treatment would have differing effects on compliance and would require differing approaches. This raises the potential need for future research studies to address specific situations in order to generate meaningful information that could be successfully used in practice.

\section{Acknowledgements}

Elanco Animal Health paid the salary of KW to undertake this review. Elanco Animal Health and all of the authors were involved in developing the aim for this review. The authors developed the protocol and methodology, undertook the review and wrote the manuscript, which Elanco Animal Health reviewed before submission.

\section{Figure Legends}

Figure 1: Flow summary of literature searches

\section{References}

1. van Riet-Nales DA, Schobben AF, Egberts TC, et al. Effects of the pharmaceutical technologic aspects of oral pediatric drugs on patient-related outcomes: a systematic literature review. Clinical therapeutics 2010;32:924-938.

2. Nieuwlaat R, Wilczynski N, Navarro T, et al. Interventions for enhancing medication adherence. The Cochrane database of systematic reviews 2014:CD000011.

3. Rash JA, Campbell DJ, Tonelli M, et al. A systematic review of interventions to improve adherence to statin medication: What do we know about what works? Prev Med 2016;90:155-169.

4. Claxton AJ, Cramer J, Pierce C. A systematic review of the associations between dose regimens and medication compliance. Clinical therapeutics 2001;23:1296-1310. 
5. Eisen SA, Miller DK, Woodward RS, et al. The effect of prescribed daily dose frequency on patient medication compliance. Arch Intern Med 1990;150:1881-1884.

6. Howick JC, I; Glasziou, P; Greenhalgh, T; Heneghan, C; Liberati, A; Moschetti, I; Phillips, B; Thornton, H. The 2011 Oxford CEBM Evidence Levels of Evidence (Introductory Document)". Oxford Centre for Evidence-Based Medicine. . http://wwwcebmnet/indexaspx?o=5653.

7. Howick JC, I; Glasziou, P; Greenhalgh, T; Heneghan, C; Liberati, A; Moschetti, I; Phillips, B; Thornton, H. Explanation of the 2011 Oxford Centre for Evidence-Based Medicine (OCEBM) Levels of Evidence (Background Document)". Oxford Centre for Evidence-Based Medicine. In. http://www.cebm.net/index.aspx?o=5653.

8. Howick JC, I; Glasziou, P; Greenhalgh, T; Heneghan, C; Liberati, A; Moschetti, I; Phillips, B; Thornton, H; Goddard, O; Hodgkinson, M. OCEBM Levels of Evidence Working Group. "The Oxford 2011 Levels of Evidence". Oxford Centre for Evidence-Based Medicine. .

http://wwwcebmnet/indexaspx?o=5653.

9. Boda C, Liege P, Reme CA. Evaluation of owner compliance with topical treatment of acute otitis externa in dogs: a comparative study of two auricular formulations. International Journal of Applied Research in Veterinary Medicine 2011;9:157-165.

10. Adams VJ, Campbell JR, Waldner CL, et al. Evaluation of client compliance with short-term administration of antimicrobials to dogs. Journal of the American Veterinary Medical Association 2005;226:567-574.

11. Barter LS, Watson AD, Maddison JE. Owner compliance with short term antimicrobial medication in dogs. Australian Veterinary Journal 1996;74:277-280.

12. Bomzon L. Short-term antimicrobial therapy--a pilot compliance study using ampicillin in dogs. Journal of Small Animal Practice 1978;19:697-700.

13. Grave K, Tanem H. Compliance with short-term oral antibacterial drug treatment in dogs. Journal of Small Animal Practice 1999;40:158-162.

14. Saevik BK, Thoresen $\mathrm{SI}$, Kristensen F. A retrospective study of hyposensitization in canine atopy based on a polyclonal ELISA test. Veterinary Research Communications 2002;26:613-624.

15. Morris JS, Dobson JM, Bostock DE. Use of tamoxifen in the control of canine mammary neoplasia. Veterinary Record 1993;133:539-542.

16. Maille V, Hoffmann J. Compliance with veterinary prescriptions: the role of physical and social risk revisited. (Special Section: Health marketing.). Journal of Business Research 2013;66:141-144. 17. Adams VJ, Campbell JR, Waldner CL, et al. Evaluation of client compliance with short-term administration of antimicrobials to dogs. Journal of the American Veterinary Medical Association 2005;226:567-574.

18. Grave $\mathrm{K}$, Tanem H. Compliance with short-term oral antibacterial drug treatment in dogs. Journal of Small Animal Practice 1999;40:158-162.

19. Saevik BK, Thoresen SI, Kristensen F. A retrospective study of hyposensitization in canine atopy based on a polyclonal ELISA test. Veterinary Research Communications 2002;26:613-624.

20. Gray SL, Mahoney JE, Blough DK. Medication adherence in elderly patients receiving home health services following hospital discharge. The Annals of pharmacotherapy 2001;35:539-545.

21. Zelko E, Klemenc-Ketis Z, Tusek-Bunc K. MEDICATION ADHERENCE IN ELDERLY WITH POLYPHARMACY LIVING AT HOME: A SYSTEMATIC REVIEW OF EXISTING STUDIES. Materia sociomedica 2016;28:129-132.

22. Thom S, Poulter N, Field J, et al. Effects of a fixed-dose combination strategy on adherence and risk factors in patients with or at high risk of CVD: the UMPIRE randomized clinical trial. JAMA 2013;310:918-929.

23. Lund EM, James KM, Neaton JD. Veterinary randomized clinical trial reporting: a review of the small animal literature. J Vet Intern Med 1998;12:57-60.

24. Sargeant JM, Thompson A, Valcour J, et al. Quality of reporting of clinical trials of dogs and cats and associations with treatment effects. J Vet Intern Med 2010;24:44-50. 
25. Moher D, Pham B, Jones A, et al. Does quality of reports of randomised trials affect estimates of intervention efficacy reported in meta-analyses? Lancet 1998;352:609-613.

26. Sargeant JM, Elgie R, Valcour J, et al. Methodological quality and completeness of reporting in clinical trials conducted in livestock species. Prev Vet Med 2009;91:107-115.

27. Devereaux PJ, Choi PT, El-Dika S, et al. An observational study found that authors of randomized controlled trials frequently use concealment of randomization and blinding, despite the failure to report these methods. Journal of clinical epidemiology 2004;57:1232-1236.

28. Hill CL, LaValley MP, Felson DT. Discrepancy between published report and actual conduct of randomized clinical trials. Journal of clinical epidemiology 2002;55:783-786.

29. Begg C, Cho M, Eastwood S, et al. Improving the quality of reporting of randomized controlled trials. The CONSORT statement. JAMA 1996;276:637-639.

30. von Elm E, Altman DG, Egger M, et al. The Strengthening the Reporting of Observational Studies in Epidemiology (STROBE) statement: guidelines for reporting observational studies. Ann Intern Med 2007;147:573-577.

31. Grindlay DJ, Brennan ML, Dean RS. Searching the veterinary literature: a comparison of the coverage of veterinary journals by nine bibliographic databases. J Vet Med Educ 2012;39:404-412. 32. Kanji N, Coe JB, Adams CL, et al. Effect of veterinarian-client-patient interactions on client adherence to dentistry and surgery recommendations in companion-animal practice. Journal of the American Veterinary Medical Association 2012;240:427-436.

33. Verker MJ, Stokrom Mv, Endenburg N. How can veterinarians optimise owner compliance with medication regimes. European Journal of Companion Animal Practice 2008;18:73-77.

34. Rohrbach BW, Lutzy A, Patton S. Attributes, knowledge, beliefs, and behaviors relating to prevention of heartworm in dogs among members of a national hunting dog club. Veterinary Parasitology 2011;176:324-332. 


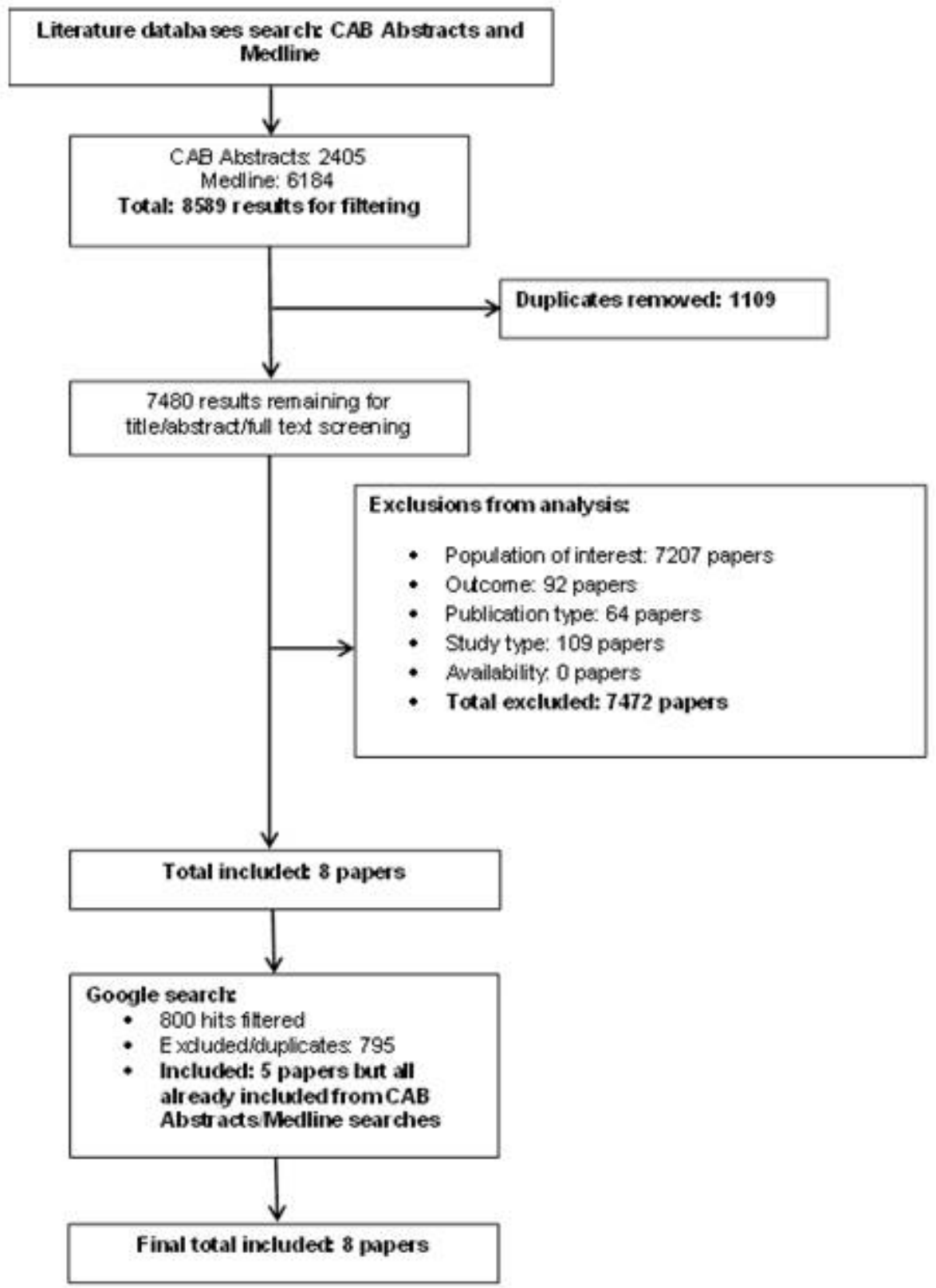

Figure 1: Flow summary of literature searches 


\begin{tabular}{|c|c|c|c|c|c|c|c|c|c|}
\hline $\begin{array}{l}\text { Study } \\
\text { reference }\end{array}$ & $\begin{array}{l}\text { Was the } \\
\text { primary aim } \\
\text { of the study to } \\
\text { examine } \\
\text { compliance? }\end{array}$ & $\begin{array}{l}\text { Study } \\
\text { design }\end{array}$ & Study setting & $\begin{array}{l}\text { Sample } \\
\text { size }\end{array}$ & $\begin{array}{l}\text { Sample } \\
\text { description }\end{array}$ & $\begin{array}{l}\text { How compliance } \\
\text { was } \\
\text { measured/determin } \\
\text { ed }\end{array}$ & $\begin{array}{l}\text { Therapeu } \\
\text { tic area }\end{array}$ & $\begin{array}{l}\text { Were } \\
\text { polypharm } \\
\text { acy } \\
\text { interventio } \\
\text { ns } \\
\text { studied? }\end{array}$ & Main findings of the study \\
\hline $\begin{array}{l}\text { Adams et } \\
\text { al, 2005 }\end{array}$ & Yes & $\begin{array}{l}\text { Cohort } \\
\text { study }\end{array}$ & $\begin{array}{l}\text { North America, } \\
\text { September } \\
2000 \text {-August } \\
2001 \text {, one } \\
\text { veterinary } \\
\text { teaching } \\
\text { hospital and } 9 \\
\text { clinics in } 3 \text { cities }\end{array}$ & $\begin{array}{l}90 \\
\text { clients/dog } \\
\mathrm{s}\end{array}$ & $\begin{array}{l}\text { Convenience } \\
\text { sample of } \\
\text { dogs requiring } \\
\text { short term } \\
\text { antimicrobial } \\
\text { administration } \\
\text { (the type, } \\
\text { dosage, } \\
\text { regimen and } \\
\text { duration of } \\
\text { treatment was } \\
\text { at the } \\
\text { veterinarians } \\
\text { discretion), } \\
\text { Clients must } \\
\text { have visited } \\
\text { the clinic } \\
\text { before to be } \\
\text { eligible, } \\
\text { owners were } \\
\text { not aware } \\
\text { compliance } \\
\text { was being } \\
\text { assessed at } \\
\text { the start of the } \\
\text { study, }\end{array}$ & $\begin{array}{ll}\text { - } & \text { Return } \\
\text { mediation pill } \\
\text { count } \\
\text { - } & \text { Client self- } \\
& \text { reporting of } \\
\text { missed doses } \\
\text { - } & \text { Electronic } \\
& \text { medication } \\
& \text { monitoring } \\
\text { - } & \text { Veterinarian } \\
\text { prediction }\end{array}$ & $\begin{array}{l}\text { Anti- } \\
\text { microbial } \\
\text { (acute } \\
\text { bacterial } \\
\text { infections) }\end{array}$ & No & $\begin{array}{l}\text { Degree of client compliance depended on } \\
\text { the definition and method of assessment - } \\
\text { all methods of assessment used were } \\
\text { significantly different from each other } \\
\text { (p<0.003) except for client self-reporting of } \\
\text { missed doses and pill count ( } p>0.05) \text {. } \\
\text { Compliance levels using different } \\
\text { assessment methods were: } \\
1 . \text { Pill count: } 80 \% \text { of clients had } \\
100 \% \text { compliance. } \\
\text { 2. Client self-reporting of missed } \\
\text { doses: } 74 \% \text { of clients reported } \\
100 \% \text { compliance. } \\
\text { 3. Electronic monitoring device data: } \\
\text { Percentage of bottle openings: } \\
48 \% \text { had } 100 \% \text { compliance. } \\
\text { Percentage of days correct } \\
\text { number of doses given: } 42 \% \text { had } \\
100 \% \text { compliance. Percentage of } \\
\text { doses given on time: } 20 \% \text { had } \\
100 \% \text { compliance. } \\
\text { 4. Veterinarians predicted } 81 \% \text { of } \\
\text { clients (72/89) would be compliant } \\
\text { or highly compliant, } 3 \text { clients } \\
\text { would be non-compliant and } 14 \\
\text { clients would be neither compliant } \\
\text { nor non-compliant. } \\
\\
\text { Clients were significantly more compliant } \\
\text { with once/twice daily dosing compared to } \\
\text { three times daily dosing (OR for being } \\
100 \% \text { compliant for } 1 \times \text { or } 2 \times \text { daily } \\
\text { compared to } 3 x \text { daily }=2.2, p=0.004) \text {. }\end{array}$ \\
\hline
\end{tabular}




\begin{tabular}{|c|c|c|c|c|c|c|c|c|c|}
\hline & & & & & & & & & $\begin{array}{l}\text { Discussion of dosing regime in light of client } \\
\text { circumstances significantly improved } \\
\text { compliance (OR for being } 100 \% \text { compliant } \\
=2.5, p<0.0001 \text { ). }\end{array}$ \\
\hline $\begin{array}{l}\text { Barter et al, } \\
1996^{11} \text {. }\end{array}$ & Yes & $\begin{array}{l}\text { Randomise } \\
d \\
\text { controlled } \\
\text { trial }\end{array}$ & $\begin{array}{l}\text { Sydney, } \\
\text { Australia: } 3 \\
\text { inner city } \\
\text { veterinary } \\
\text { practices }\end{array}$ & $\begin{array}{l}22 \\
\text { clients/dog } \\
\mathrm{s}\end{array}$ & $\begin{array}{l}\text { Dogs with } \\
\text { acute, } \\
\text { uncomplicated } \\
\text { bacterial } \\
\text { infections, in } \\
\text { first } 5-7 \text { days } \\
\text { of treatment, } \\
\text { not receiving } \\
\text { any other } \\
\text { medical } \\
\text { treatments - } \\
\text { owners } \\
\text { agreeable to } \\
\text { participation. } \\
\text { Owners were } \\
\text { not aware } \\
\text { compliance } \\
\text { was being } \\
\text { assessed at } \\
\text { the start of the } \\
\text { study. }\end{array}$ & $\begin{array}{l}\text { Electronic } \\
\text { monitoring } \\
\text { (EMR) - used } \\
\text { to determine } \\
\text { doses given } \\
\text { (\%), optimum } \\
\text { interval, doses } \\
\text { per day }\end{array}$ & $\begin{array}{l}\text { Antimicrobi } \\
\text { al } \\
\text { (amoxicillin } \\
- \\
\text { clavulanate } \\
\text { only for } \\
\text { acute } \\
\text { bacterial } \\
\text { infections) }\end{array}$ & No & $\begin{array}{l}\text { There was no significant difference in } \\
\text { compliance assessed by 'mean doses } \\
\text { given' between twice (BID) and three times } \\
\text { (TID) daily dosing (TID } 92 \% \text {, BID } 76 \% \text {, } \\
\text { median for both groups } 93 \%, p>0.05 \text { ). } \\
\text { Average of } 32 \% \text { of doses given within } \\
\text { optimum time periods, there was no } \\
\text { significant difference between dosing } \\
\text { regimens (BID } 43 \% \text {, TID } 22 \%, p>0.05 \text { ). } \\
\text { Number of doses per day correctly } \\
\text { administered on } 56 \% \text { of days for BID and } \\
59 \% \text { of days for TID (no statistical } \\
\text { comparison). } \\
\text { The mean proportion of all doses given was } \\
84 \% \text { with the exact prescribed number of } \\
\text { doses being given by } 6 / 22 \text { owners ( } 27 \% \text { ). } 1 \\
\text { owner was overcompliant (gave an extra } \\
\text { dose). } 15 / 22 \text { ( } 68 \% \text { ) owners gave less than } \\
\text { the prescribed number of doses. } 4 / 22 \\
\text { owners ( } 18 \% \text { ) gave less than } 80 \% \text { of } \\
\text { prescribed doses. }\end{array}$ \\
\hline $\begin{array}{l}\text { Boda et al, } \\
2011^{9} \text {. }\end{array}$ & Yes & $\begin{array}{l}\text { Randomise } \\
\text { d } \\
\text { controlled } \\
\text { trial and }\end{array}$ & $\begin{array}{l}7 \text { veterinary } \\
\text { practices in } \\
\text { France and } \\
\text { Germany }\end{array}$ & $\begin{array}{l}42 \\
\text { clients/dog } \\
\mathrm{s}\end{array}$ & $\begin{array}{l}\text { Dogs of } \\
\text { various breeds } \\
\text { presenting for } \\
\text { bilateral acute }\end{array}$ & $\begin{array}{l}\text { Weight of } \\
\text { returned } \\
\text { product used } \\
\text { to determine }\end{array}$ & $\begin{array}{l}\text { Antimicrobi } \\
\text { al and anti- } \\
\text { inflammator } \\
\text { y (otitis }\end{array}$ & No & $\begin{array}{l}\text { No significant difference between owner } \\
\text { reported missed doses between the two } \\
\text { treatments ( } p=0.4615) \text {. }\end{array}$ \\
\hline
\end{tabular}




\begin{tabular}{|c|c|c|c|c|c|c|c|c|c|}
\hline & & $\begin{array}{l}\text { cross } \\
\text { sectional } \\
\text { questionin } \\
\text { g of } \\
\text { owners }\end{array}$ & & & $\begin{array}{l}\text { otitis externa, } \\
\text { none had } \\
\text { received any } \\
\text { treatment in } \\
\text { the previous } 7 \\
\text { days. } \\
\text { Owners were } \\
\text { not aware } \\
\text { compliance } \\
\text { was being } \\
\text { assessed at } \\
\text { the start of the } \\
\text { study. }\end{array}$ & $\begin{array}{l}\text { compliance } \\
\text { ratio (number } \\
\text { of actual } \\
\text { doses } \\
\text { administered } \\
\text { by owners) } \\
\text { Owner } \\
\text { questionnaire } \\
\text { by phone to } \\
\text { determine } \\
\text { self-reporting } \\
\text { of missed } \\
\text { doses } \\
\text { Vet reporting } \\
\text { of predicted } \\
\text { owner } \\
\text { compliance }\end{array}$ & $\begin{array}{l}\text { externa; } \\
\text { topical } \\
\text { preparation } \\
\text { ) }\end{array}$ & & $\begin{array}{l}\text { Percentage of non-compliant owners based } \\
\text { on compliance ratio was } 21.1 \%(4 / 19) \text { for } \\
\text { Easotic and } 78.9 \%(15 / 19) \text { for Surolan. } \\
\text { Variance of the compliance ratio was } \\
\text { significantly different between treatments } \\
\text { (Easotic compliance ratio } 1.06+/-0.35 ; \\
\text { Surolan compliance ratio } 0.8+/=0.68 ; p= \\
0.008) \text {. } \\
\text { Difficulty in applying the right dose was } \\
\text { reported by } 0 / 4 \text { non-compliant owners in } \\
\text { the Easotic group and } 14 / 15 \text { in the Surolan } \\
\text { group. } \\
\text { Misunderstanding of the medical condition } \\
\text { was reported by } 2 / 4 \text { non-compliant owners } \\
\text { in the Easotic group and } 5 / 15 \text { in the } \\
\text { Surolan group. }\end{array}$ \\
\hline $\begin{array}{l}\text { Bomzon et } \\
\text { al, } 1978^{12} \text {. }\end{array}$ & Yes & $\begin{array}{l}\text { Case } \\
\text { series and } \\
\text { cross } \\
\text { sectional } \\
\text { questionin } \\
\text { g of } \\
\text { owners }\end{array}$ & $\begin{array}{l}2 \text { month period } \\
\text { in a small animal } \\
\text { practice in South } \\
\text { Africa }\end{array}$ & $\begin{array}{l}26 \\
\text { clients/dog } \\
\mathrm{s}\end{array}$ & $\begin{array}{l}\text { Dogs with } \\
\text { acute bacterial } \\
\text { infections that } \\
\text { could be } \\
\text { treated with } \\
\text { ampicillin - } \\
\text { prescribed } 3 \\
\text { times daily for } \\
5-7 d \\
\text { Owners were } \\
\text { not aware } \\
\text { compliance } \\
\text { was being } \\
\text { assessed at } \\
\text { the start of the } \\
\text { study. }\end{array}$ & $\begin{array}{l}\text { Measurement } \\
\text { of remaining } \\
\text { medicine }\end{array}$ & $\begin{array}{l}\text { Antimicrobi } \\
\text { al } \\
\text { (ampicillin } \\
\text { only for } \\
\text { acute } \\
\text { bacterial } \\
\text { infections) }\end{array}$ & No & $\begin{array}{l}25 / 26 \text { prescriptions were issued within } 30- \\
90 \text { minutes of the consultation, the } \\
\text { remaining one was completed the next day. } \\
\text { Overall } 73 \% \text { of owners (19/26) did not } \\
\text { adhere to instructions: } 50 \% \text { of owners } \\
\text { (13/26) had more antibiotic left than they } \\
\text { should have, } 23 \%(6 / 26) \text { had less } \\
\text { remaining than they should have and } 27 \% \\
(7 / 26) \text { had the correct amount remaining. } \\
\text { All underdosing owners cited the reason for } \\
\text { underdosing as being that they were unable } \\
\text { to comply with instructions due to being at } \\
\text { work during the day. }\end{array}$ \\
\hline $\begin{array}{l}\text { Grave et al, } \\
1999^{13} \text {. }\end{array}$ & Yes & $\begin{array}{l}\text { Cohort } \\
\text { study }\end{array}$ & $\begin{array}{l}\text { Outpatient } \\
\text { department at } \\
\text { Norwergian } \\
\text { college of } \\
\text { veterinary } \\
\text { medicine (dogs }\end{array}$ & $\begin{array}{l}95 \\
\text { clients/dog } \\
\mathrm{s}\end{array}$ & $\begin{array}{l}\text { Dogs suffering } \\
\text { from acute } \\
\text { bacterial } \\
\text { infections } \\
\text { treated with } \\
\text { either TMPS }\end{array}$ & $\begin{array}{l}\text { - Pill count } \\
\text { performed by } \\
\text { owners - } \\
\text { information } \\
\text { gathered by } \\
\text { telephone }\end{array}$ & $\begin{array}{l}\text { Antimicrobi } \\
\text { al (acute } \\
\text { bacterial } \\
\text { infections) }\end{array}$ & No & $\begin{array}{l}100 \% \text { compliance was exhibited by } 44 \% \text { of } \\
95 \text { owners/animals. } 25 \% \text { had } 90-100 \% \\
\text { compliance and } 19 \% \text { had } 80-90 \% \\
\text { compliance. } 12 \% \text { had a compliance rate } \\
\text { that was less than } 80 \% \text {. }\end{array}$ \\
\hline
\end{tabular}




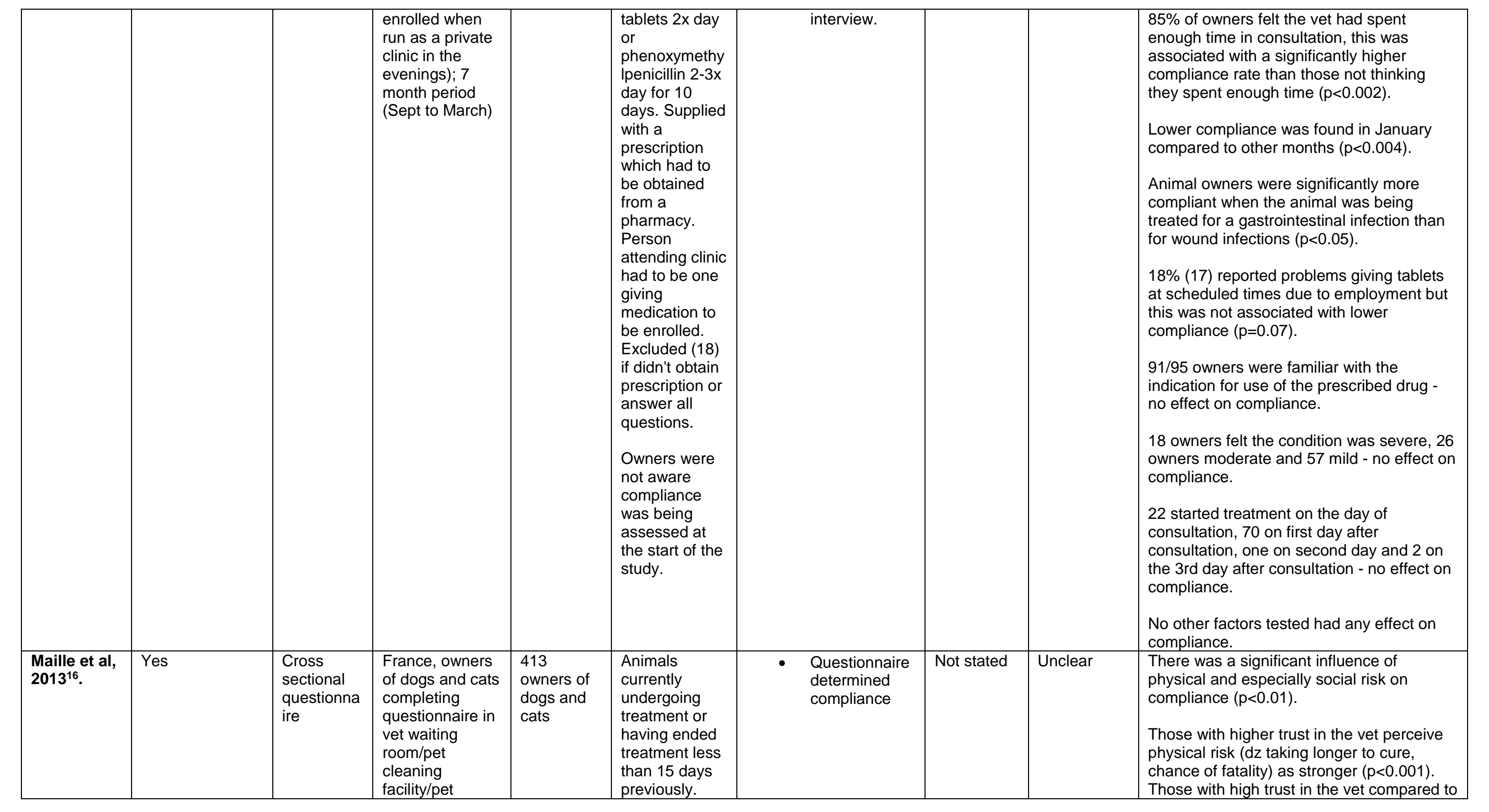




\begin{tabular}{|c|c|c|c|c|c|c|c|c|c|}
\hline & & & $\begin{array}{l}\text { shop/public } \\
\text { garden/hyperma } \\
\text { rket pet } \\
\text { department or } \\
\text { street. }\end{array}$ & & & & & & $\begin{array}{l}\text { low trust have a stronger positive influence } \\
\text { of perceived physical risk ( } p<0.01) \text {, under } \\
\text { these circumstances physical risk becomes } \\
\text { more determinant than social risk. } \\
\text { Physical risk influences those with high and } \\
\text { low attachment to their pet ( } p<0.01) \text {, but } \\
\text { influences those with high attachment most, } \\
\text { again under such circumstances physical } \\
\text { risk becomes more important than social } \\
\text { risk. }\end{array}$ \\
\hline $\begin{array}{l}\text { Morris et al, } \\
1993^{15} \text {. }\end{array}$ & No & $\begin{array}{l}\text { Cross } \\
\text { sectional } \\
\text { questionin } \\
\text { g of } \\
\text { owners for } \\
\text { compliance } \\
\text { during trial. } \\
\text { RCT for } \\
\text { tamoxifen } \\
\text { vs no } \\
\text { treatment. }\end{array}$ & $\begin{array}{l}\text { General } \\
\text { practices within } \\
10 \text { mile radius of } \\
\text { Cambridge Vet } \\
\text { School } \\
\text { submitted } \\
\text { samples } \\
\text { (excised } \\
\text { mammary } \\
\text { masses) for } \\
\text { histopathology } \\
\text { between April } \\
1991 \text { and } \\
\text { December } 1992 . \\
\text { Spayed bitches } \\
\text { with } \\
\text { benign/malignan } \\
\text { t tumours then } \\
\text { included in } \\
\text { ongoing trial } \\
\text { comparing } \\
\text { tamoxifen and } \\
\text { no treatment. }\end{array}$ & $\begin{array}{l}93 \text { bitches } \\
\text { enrolled - } \\
\text { only } 51 \\
\text { spayed } \\
\text { and eligible } \\
\text { to enter } \\
\text { drug trial }\end{array}$ & $\begin{array}{l}51 \text { spayed } \\
\text { bitches with } \\
\text { benign/malign } \\
\text { ant excised } \\
\text { mammary } \\
\text { tumours } \\
\text { randomised to } \\
\text { receive } \\
\text { tamoxifen or } \\
\text { no treatment. }\end{array}$ & - $\quad$ Not reported & Oncology & No & $\begin{array}{l}5 / 23 \text { randomised to tamoxifen failed to } \\
\text { comply - reasons were: owner refusal after } \\
\text { initial consent ( } 3 \text { ), animal unwell (1) and } \\
\text { animal was euthanased before treatment } \\
\text { began (1). }\end{array}$ \\
\hline $\begin{array}{l}\text { Saevik et } \\
\text { al, 2002 }\end{array}$ & Yes & $\begin{array}{l}\text { Cohort } \\
\text { study }\end{array}$ & $\begin{array}{l}\text { Norway referral } \\
\text { practice }\end{array}$ & $\begin{array}{l}130 \\
\text { clients/dog } \\
\mathrm{s}\end{array}$ & $\begin{array}{l}\text { Dogs } \\
\text { hyposensitised } \\
\text { between June } \\
1997 \text { and June } \\
1999 \text {, various } \\
\text { breeds and } \\
\text { mixed breeds, } \\
\text { sexes and } \\
\text { ages. Dogs }\end{array}$ & $\begin{array}{ll}- & \text { Review of } \\
\text { ordering forms } \\
\text { for } \\
\text { hyposensitisati } \\
\text { on mix } \\
\text { Telephone } \\
\text { interviews with } \\
\text { owners } \\
\text { NB }\end{array}$ & $\begin{array}{l}\text { Dermatolog } \\
y\end{array}$ & No & $\begin{array}{l}\text { Telephone interviews were completed for } \\
121 \text { dogs }(93.1 \%) .80 \text { dogs }(66.1 \%) \text { treated } \\
\text { for at least } 9 \text { months; } 22.3 \%(27 / 121) \\
\text { discontinued after } 3 \text { months, } 11.6 \% \\
(14 / 121) \text { after } 6 \text { months, } 21.5 \%(26 / 121) \\
\text { after } 9 \text { months and } 14.9 \%(18 / 121) \text { after } \\
12-21 \text { months. } 54 \text { dogs }(44.6 \%) \text { had } \\
\text { maintenance injections ordered for them. } \\
81 \% \text { of owners gave the injections at home. }\end{array}$ \\
\hline
\end{tabular}




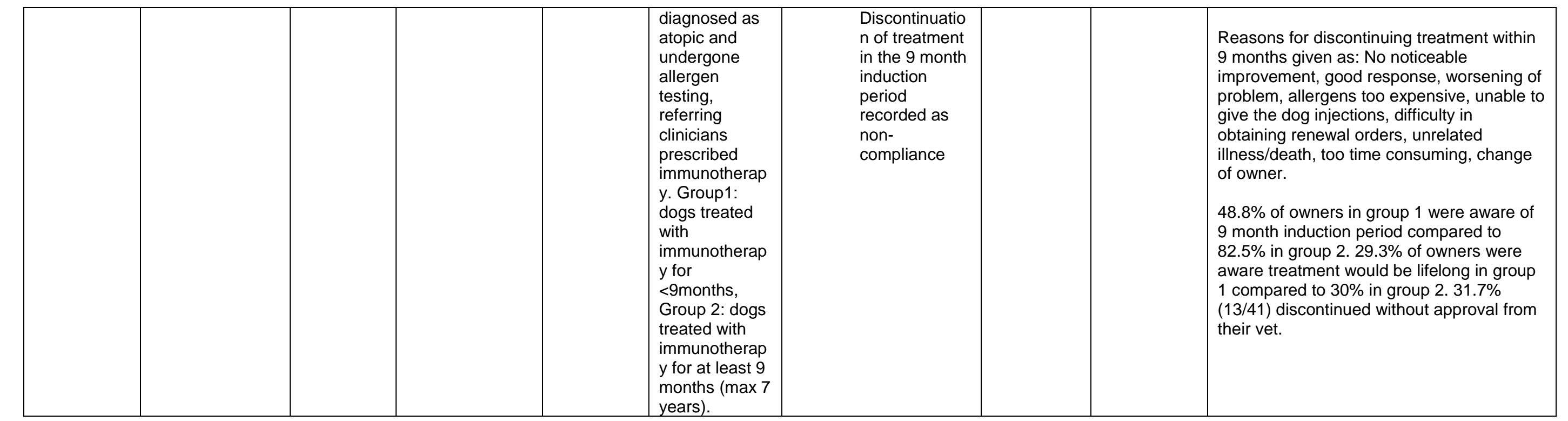

